\title{
The Discussion of Theory Review and Practice on Enterprise Executives Incentive
}

\author{
Quanzhou Li \\ School of Management, Jinan University, Guangzhou, China \\ Email: quanzhou220@163.com
}

Received 23 February 2015; accepted 20 March 2015; published 24 March 2015

Copyright (C) 2015 by author and Scientific Research Publishing Inc.

This work is licensed under the Creative Commons Attribution International License (CC BY). http://creativecommons.org/licenses/by/4.0/

(c) (7) Open Access

\begin{abstract}
Trying to analysis on the main basis of the tenant theory and the contingency theory, and then suggest some scientific, reasonable and effective incentive methods for the enterprise operator-managers, aiming to put forward some thoughts to set up a reasonable incentive mechanism.
\end{abstract}

Keywords

Tenant Theory, Contingency Theory, Enterprise Executives, Incentive Mechanism

\section{Introduction}

Nowadays, science and technology are rapidly progressing, economy continually developing, society constantly progressing, and competition is increasingly fierce. Under the whole back of the limitation and determination of the natural resource, all of the competition will own to talent competition. A company's short-term development, whether smooth or not, depends on its talents' power at present, that is to say, its long-term development lies on the human resources strategy. Therefore, the enterprise that only gains a competitive advantage in the talent competition can only be in an impregnable position. Enterprises will face two major problems: the first is, how do enterprises attract more high-quality and high-tech people as their main center power, that means "attracting talents"; the second is, how do enterprises dig up the potential of existing talents and how to inspire them to develop their biggest impact, that means "making the best use of people". In this paper, we only talk about and analyze the second problem, and define it as "how to incent people better", and we will not consider other problems such as person- post matching; enterprise refers to the general enterprises, regardless of the specific industry or enterprise's unusual properties, such as monopoly industries or enterprises.

Executives as important enterprise human capital investment, in the daily operations, are the timing controllers of enterprises. Improving the enterprises' executive incentive mechanisms has much important significance, 
such as arousing top managers' high work enthusiasm, building their loyalty to the enterprise, playing their biggest effect and so on. Above all, these can make the enterprise obtain rapid development in a short term. Furthermore, long-term development also gets reasonable time and good planning. Meanwhile, for business owners or shareholders, short-term interests and long-term interests are both a way to secure and maintain. As executives, such a special place plays a decisive role in the development of the enterprise, so the establishment of the enterprise's executive incentive system has become a corporate priority. In this paper, on the basis of tenant theory and contingency theory, we study the effect of the executive incentive mechanism of the enterprise, in the hope to provide some ideas to design and build enterprise executive incentive mechanism.

\section{Incentive}

In the management, we defined incentive as, to achieve the specific objectives of the organization, and meet the needs of the staff about the spiritual or material, to stimulate the motivation, eventually make its produce to realize the process of the specific behavior of organizational goals, it contains meeting needs, stimulating the motivation, guiding the behavior these three steps. Incentive means to inspire and encourage, is indispensable to the management process and activities. All people's actions are caused by some kind of motivation, motivation is a state of mind, it works on people's actions like inspiring, promoting and strengthening, however, motivation is excited by the needs of the heart. The motivation of enterprise executives are independence, innovation and the financial revenue. Among those the two former as the spiritual level, the third party for the material level. We can take different incentives to meet executives about the different hierarchy of needs [1].

About the incentive ways, there are many kinds of theories and methods in academic world at present, such as the famous Maslow's hierarchy of needs, incentives-care two-factor theory, and so on. Maslow's hierarchy of needs theory divided the demands into five parts, according to the level gradually, like ladder from low to high, respectively: physiological needs, security needs, emotional and belonging needs, respect needs, self-actualization needs. In two-factor theory, incentive factor is the satisfaction one, it will get satisfaction and motivation; hygiene factor is the dissatisfaction one, without it, people will produce negative behavior. It has its own characteristics, and it is based on the needs of the organization members and guided by the theory of demand; incentives have different types such as material motivation and spirit motivation, extrinsic motivation and intrinsic motivation and so on. In fact, all the types could be summarized as two main types: positive incentives and negative incentives.

Remuneration incentive is based on the value of the executives' human capital, labor created value and the situation of executive talent market's supply and demand [2]. In this paper, the study of the enterprise executive compensation incentive is assuming that executives' talent market's supply and demand are balanced. Besides, assuming that there is no contract cost, and circulation is free.

Effective incentive can be a driving force assurance for the development of the organization, to help it achieve organizational goals [3]. Meanwhile, for their employees, effective incentive can also make them reach their potential, to make themselves get better development, and then promote them realize their own goals in life.

\section{Tenant Theory}

\subsection{Introduction to the Theory of Tenants}

Tenant farmers theory is proposed by a famous economist Wuchang Zhang in 1969 in "the tenants", it mainly made the new explanation for the divided tenancy system from the viewpoint of the modern new institutional economics, it overthrew the traditional theory of the past, and established the theory of "new tenants", finally, laid the foundation of modern economics of contracts [4].

\subsection{Tenants Theory Using in Modern Enterprises}

Nowadays, economic development and communication between China and western countries constantly closer, western management ideas constantly introduced into China, its also influence thoroughly on the development of the our country enterprises. Management of large enterprises in our country gradually transfer from the family-owned business and collectivization operation to professional managers. This leads to separation of ownership and management in corporations, besides, the relationship between the operators and the owners is principal-agent relationship, making the enterprise operator has the nature of the tenants. We usually think that compa- 
nies' investment is divided into two kinds: capital and labor. The owner of the capital can be thought of as "landlord" in the theory of tenant farmers and the enterprise operators can be regarded as "tenants". The none executive staffs are not seen as a land of investment, and the assistance of the executives is the none-capital investment of the production and the improvement.

\subsection{Tenant Theory Analysis in the Enterprise Executive Compensation Incentive}

Taiwan has carried on the land reform in 1949. In the reform, authorities stipulated the landlord rent shall not exceed $37.5 \%$ of the agricultural products. But what makes the economists incredible is that under the authority of the rigid constraint, Taiwan's agricultural production rise sharply instead of declining. Why did this happen? Later, after repeated research, Wuchang Zhang proposed the tenant theory, and then successfully explained the phenomenon.

Here, the landlords are equivalent to the companies' owners, investing capital; farmers are equivalent to the business operators, putting into labor. When farmers percentage increases, farmers' on the land revenue will be higher than to put labor into other areas, farmers will be able to move the labor element, into the land, and to improve the capacity of the land. If the proportion of land capacity increase is far greater than the proportion of the landlords' income loss in divided into, so the earnings of the landlords will increase. For a simple numeric example, if A landlord now put all the land under the cultivation of farmers $\mathrm{B}$, their annual revenue is $1000 \mathrm{ki}-$ lograms of wheat, the two into A ratio of 7:3, the landlord A yield 700 kilograms of wheat, so the left 300 kilograms of wheat are farmer B revenue. If the tenant farmers theory was improved, it is divided into locating 6:4 proportion. When farmer B precision farming land, allow it to increase production to 1500 kilograms, the landlord A revenue increased to 900 kilograms of wheat, farmer B's earnings increased to 600 kilograms of wheat. Before and after comparison, the landlord A earnings increased by 200 kilograms of wheat, farmer, of course, is the biggest beneficiaries.

The theory is applied to the enterprises similarly, so in the enterprise, increase the proportion of the enterprise operators can motivate them, and then may increase its revenue rather than reduce it.

\subsection{Summary and Recommendations}

\subsubsection{Capital Ratio Drops, Labor Rise, Can Motivate Executives}

Improve labor proportion, can motivate enterprise executives spend more labor, to get more profits. At the same time, the increase of labor income can make the company more attractive, and attract more talents, promoting the reform of enterprise innovation and increasing the enterprise's overall revenue.

In this case, if company owners fell into the proportion of appropriate capital gains, their revenue will not reduce but increase. When take effective measures, suggested that adopts the principle of "a small amount many times". That is to say, lower capital gains rates for many times, and control the magnitude of decline every time.

\subsubsection{Perfect Manager Market and Capital Market Is an Important Guarantee of Enterprise Executive Compensation Incentive}

Financial crisis in 2008 , is due to the capital gain sharing is too low, prompting non-production enterprise executives bold innovation and ignore the risk, that amplifies the risk to a great extent. Collective enterprise production efficiency is low, because of the low proportion of labor gain sharing. The reason why it appears unreasonable proportion of too high or too low on capital gain sharing is that, the formulation of capital gain sharing proportion is restricted by the risk factors, transaction cost and the legal system in the business environment. So, to improve the enterprise executive compensation incentive, improve the legal system and the market mechanism is very necessary, besides, promote the free flow of manager market and capital market are also very necessary.

\section{Contingency Theory}

\subsection{Contingency Theory Overview}

Contingency theory [5] is developed in the late 1960's and early 70's on the basis of the empirical school, its a further management theory. It is based on the west specific situation in the organization management and the specific concrete countermeasures of strain. From the 1970's, contingency theory in the United States has been risen, and it has been caused widely attention. The word "contingency" has the meaning of "change according to 
the specific situation" or "depend on the specific situation".

The core content of contingency theory is that there is no invariable management mode in the world. Management is not so much a broad and profound theory, but a real very strong and practical technology; it is a changing art rather than a science. Contingency management can reflect the composition of technology and art. A good leader should be a fickle and resourceful person, that is to say, they should transform their own leadership style in a timely manner depending on the environment. Contingency theory tells that, managers should constantly adjust themselves, making themselves lose no time to adapt to the change of the outside world, or putting themselves in an adaptable environment.

\subsection{The Contingency Theory Analysis of the Enterprise Executives Incentive}

To introduce the contingency theory to the enterprise executives' incentive, is according to enterprise and business executives' two-sided dynamic change, which provides a guarantee to the effectiveness of the enterprise executives' incentive system. Its main characteristic is no fixed pattern and incentives exist, and have dynamic changes.

In the design of executive incentive mechanism, the internal and external environment of enterprises should be considered first. Internal environment including enterprise culture, enterprise scale, enterprise financial and income situation, enterprise development stage, the future development of the enterprise prospect, etc.; external environment including enterprise industry competition situation, the nature of the industry, industry prospects, the tendency of national legal system of industry, the change of the market cycle and stability, etc.

Second, determine the incentive object — corporate executives personal circumstances. Executives are generally highly educated and high-quality personnel, their demand level and desirability have big differences, so we should according to the principle of contingency theory to take different incentives for different situation. Executives generally have little material demand for financial incentives; the emphasis is spiritual needs such as independence and innovation opportunities.

\subsection{Summary and Recommendations}

In the modern enterprise management, and research activities, corporate executives incentive mechanism has always been a hot topic, but it's also a difficult problem. With the globalization of economy, the increase number of uncertain factors is becoming more and more, so enterprise development in turmoil wants to meet a perfect subjective standard is clearly unrealistic. The introduction of the contingency theory will direct the executive incentive mechanism in a very long period of time.

Executives are generally highly educated and high-quality personnel, their demand level and desirability have big differences, so we should according to the principle of contingency theory to take different incentives for different situation. Executives generally have little material demand for financial incentives; the emphasis is spiritual needs such as independence and innovation opportunities. Proposal, under the basic principles, try to respect their opinion, to ease restrictions on their jobs properly, but proper supervision is needed, in case of bad situations happen for business.

\section{Conclusions}

This paper simply introduces the peasant theory and contingency theory's effects and application in designing and formulating the enterprise executive compensation incentive mechanism [6]. Contingency theory has universal applicability, for almost all of the enterprise executive compensation incentive mechanisms play a certain guiding role; tenant theory is a research method which has some certain scope and incentives.

When enterprises set out executive incentive mechanism, they should base on principles of contingency theory. Besides, the incentive mechanism thought and theory mentioned in the tenant theory should be considered. There is no changeless management as mentioned in the contingency theory; things will always be in a state of turmoil. In the turmoil, making full use of the rule is the guiding ideology in enterprise executive incentive mechanism designing.

\section{References}

[1] Xiao, W.S. (2010) The Reviewing of the Monopoly Executive Compensation Incentive Theory-Based on the Angle of Executive. Modern Business Trade Industry, No. 5, 67-73.

[2] He, J.T. (2006) The Combination Study of Senior Management Incentive in the Listed Company. School of Business 
Administration, Hunan University, Changsha.

[3] Wu, X.Q. and Ying, Z.Y. (2003) The Incentive Mechanism and Capital Structure Theory with Chinese Empirical. Management World, 6, 132-141.

[4] Zhang, W.C. (2000) The Tenant Theory. Chapter Two, Beijing Commercial Press, Beijing.

[5] Zheng, L.B. and He, F. (2010) The Influence of the Contingency Theory to the Enterprise Executive Incentive Mechanism. Henan Building Materials, No. 6, 33-38.

[6] Duffhues, P. and Kabir, R. (2008) Is the Pay-Performance Relationship Always Positive? Evidence from the Netherlands. Journal of Multinational Financial Management, 18, 45-60. http://dx.doi.org/10.1016/j.mulfin.2007.02.004 